\title{
Identity Construction of Chinese Business English Teachers from the Perspective of ESP Theory
}

\author{
Guo Guihang ${ }^{1} \&$ Zhu Miao ${ }^{1}$ \\ ${ }^{1}$ School of English for International Business, Guangdong University of Foreign Studies, China \\ Correspondence: Guo Guihang, School of English for International Business, Guangdong University of Foreign \\ Studies, No. 2 Baiyundadaobei, Guangzhou 510420, China.
}

Received: February 18, 2019

Accepted: March 21, 2019

Online Published: June 29, 2019

doi:10.5539/ies.v12n7p20

URL: https://doi.org/10.5539/ies.v12n7p20

\begin{abstract}
As an interdisciplinary major, Business English has a distinct difference from General English. Therefore, Business English teachers and General English teachers are also very different. However, nowadays, most Business English teachers in most colleges are with the educational background of English Language and Literature. They are facing serious problems of teacher identity construction. As Business English is generally considered to be a branch under English for Specific Purpose (ESP), there is a close connection between Business English and ESP. Therefore, ESP theory can provide a theoretical basis for the development of Business English program and can also provide some guidance for the identity construction of Business English teachers. Based on Needs Analysis and learning-centred approach of ESP theory, combining former researches of this field and observation findings of actual Business English classroom in a university, this article summarizes three identities that Business English teachers should construct: teaching practitioners and researchers, learners, and businesspeople. The study of teacher identity is of great significance to the successful construction of multidimensional teacher identities for Business English teachers and to the realization of their professional development.
\end{abstract}

Keywords: ESP, business English, teacher identity

\section{Introduction}

The first Business English undergraduate program established at universities has been officially approved by the Ministry of Education in 2007. Up to now, about 300 colleges and universities across the country have set up undergraduate programs of Business English, which has produced large numbers of talents for social and economic development. The construction of China's Business English Program also entered a development period of standardization, specialization, systematization, and theorization (Zhang, 2014). Many domestic scholars have done a lot of research on the construction and development of Business English discipline, the requirements of Business English teachers' ability and quality, and on the demand and training model of Business English talents (Weng, 2014; Wang \& Zhang, 2011; Wang, 2016). However, there are still many problems that need to be solved immediately in the construction and development of Business English in China. Among them, the construction of teaching staff is one of the most serious problems. Due to the short development time of Business English in China, there is currently almost no institution that specializes in training Business English teachers, making the professionals very insufficient. At present, Business English teachers in most colleges are transformed from traditional English language teachers. Insufficient business knowledge and practical experience make these Business English teachers who have just transformed from ordinary English teachers face severe identity crisis and the challenge of identity reconstruction under the new teaching environment.

English for Specific Purposes (ESP), which corresponds to English for General Purposes (EGP), refers to "English related to a specific occupation or special purposes" (Mo, 2008, p. 1). The research area of ESP generally involves the definition and classification of ESP, curriculum design, needs analysis and so on. Its main point of view is that the curriculum design and teaching activities should be centered on the needs of the learners, emphasizing the actual needs of the learners such as employment. Hutchinson and Waters (2002, p. 19) believe that ESP must be seen as an approach not as a product. In other words, ESP is not a specific thing, but a learning idea or method. As a branch under ESP, Business English has a close relationship with ESP. Therefore, 
ESP theory can provide ideas for the development of Business English and can also provide guidance for professional development of Business English teachers. There are quite a few researches on ESP in China. However, there are few researches on the development of Business English teachers from the perspective of ESP. Moreover, the number of research on the construction of Business English teachers' identity from the perspective of ESP is almost zero. Therefore, this article will start from the perspective of ESP, based on Needs Analysis and Learning-centred approach of ESP theory, combining with the investigation and observation of 4 teachers and their classes provided by Guangdong University of Foreign Studies for the first-year postgraduates of Business English major, to explore multidimensional teacher identity that Chinese Business English teachers should construct and to put forward some ideas on the practical approaches to achieve this identity construction.

\section{Literature Review}

\subsection{Research on Teacher Identity}

Beijaard, Meijer, and Verloop (2004) summarize three categories of research on teacher identity, namely, "teachers' professional identity formation or alteration", "the identification of characteristics of teachers' professional identity", and "studies in which professional identity is (re)presented by teachers". This paper mainly discusses the multiple identities of Business English teachers, which belongs to the first category of the three-"teachers' professional identity formation or alteration".

In the past few decades, research on teacher identity has become a specialized research area. In order to explain this concept, many scholars have done a lot of research on its definition from the perspective of social science and philosophy. However, in foreign studies, there is no clear definition of teacher identity. Most scholars regard teacher identity as "an ongoing process of integration of the personal and the professional sides of becoming and being a teacher" (Beijaard, Meijer, \& Verloop, 2004). Identity is dynamic, and under the influence of personal internal factors, teacher identity changes over time, such as emotion (Rodgers \& Scott, 2008; Van Veen \& Sleepers, 2006; Zembylas, 2003). The external environment will also have an impact on teacher identity, such as work and life experiences in specific contexts (Flores \& Day, 2006; Rodgers \& Scott, 2008; Sachs, 2005). Many foreign scholars focus on the influence of personal and social factors on teacher identity. For example, Goodson and Cole (1994) and Volkman and Anderson (1998) argued that these concepts or images of self strongly determine the way teachers teach, the way they develop as teachers, and their attitudes toward educational changes. Beauchamp and Thomas (2009) put forward that the school environment, the nature of the learner population, the impact of colleagues and of school administrators can all be influential in shaping a student or new teacher identity, as of course are their own experiences as learners in schools. As well, the emotion brought to the context and that generated by the context will affect this identity.

From the foreign studies on teacher identity, we have concluded that self and social factors will influence the construction and change of teacher identity. This has a certain enlightening effect on the identity construction of Business English teachers in China. The rapid development of China's foreign economy has made the demand for high-quality personnel who have a good command of both English and business knowledge grow rapidly. In 2007, the Ministry of Education approved the addition of Business English program into undergraduate programs. Also the construction of Business English discipline has entered a new stage of development. Faced with this special social background and education adjustment, Chinese Business English teachers need to adjust their self-positioning and actively construct multiple teacher identities to meet the special needs of self and society for the professional teachers.

By searching the keyword "teacher identity" (in Chinese) in "China National Knowledge Infrastructure", we found that although China's research on teacher identity has achieved certain achievements, it is mainly focused on the study of identity of General English teachers, among which there were only 9 articles on the study of teacher identity of ESP teachers. There were only 3 articles showed using the keyword "Business English teacher identity". This shows that China's study on teacher identity of Business English teachers is still far from enough.

China's research on teacher identity has a history of about 20 years. Some scholars are concerned about the research on teachers' identity, such as the influencing factors and construction approaches of teacher identity (Xun, 2012; Ye, 2014; Li, 2009). For example, Zhang (2019) explored the starting point and process of teacher identity construction based on three learning theories- traditional learning theory, situated learning theory and expansive learning theory. Some scholars focus on the research on the relationship between teacher's professional development and the role of teachers (Ye, 2015; Wang, Bai, \& Xue, 2015). Research in these areas is mainly qualitative analysis, and empirical research is few. However, in recent years, some studies have begun to focus on the dynamic construction of teacher identity in the actual classroom. For example, $\mathrm{Li}$, Liu, and Wei (2017) studied the construction of multi-dimensional teacher identity in the "flipped classroom "model using the 
"English Writing" classroom as an example. It was found that in this teaching mode, the teacher identity of English writing teachers experienced three conversional stages. Zhang (2011) studied the identity construction features of online English teachers in online learning through case studies. The study found that online English teachers used different technical strategies to construct social-relationship and teaching-type identities, with the first identity being particularly prominent. In addition, teacher identity also has the characteristics of multiplicity, periodicity, and continuity, which has a positive effect on online learning. Using a semi-structured interview research method, Xu, Qin, and Yang (2017) conducted a case study of a high school novice English teacher, analyzing the process of teacher identity development, the main influencing factors, and how these factors affecting the identity development of a novice teacher.

\subsection{Professional Competence and Qualities Required of Business English Teachers}

The National Criterion for Teaching Quality of BA in Business English (herein after referred to as the National Criterion) clearly requires that Business English teachers should be highly-educated, qualified in English basic skills and have professional knowledge, teaching ability, scientific research ability, practical ability, and the ability to use modern educational information technology to carry out classroom teaching and teaching reform (Wang, 2015). There are lots of domestic studies in this area. Some scholars put forward their own views on the professional competence and quality required of Business English teachers. For example, Wang and Ge (2016) believe that the professional competence of qualified Business English teachers should consist of language ability, teaching ability, professional knowledge, and practical ability. Zhang and Tang (2012) believe that Business English teachers have the characteristics of professionalism, teaching effectiveness, and uniqueness. The construction of Business English teachers' ability elements must begin with the preparation of syllabus, the standardization of professional standards, the construction of teaching materials, the planning of professional orientation of teachers, and the training of teachers. Li (2018) argues that Business English teachers must have the ability to fully understand the latest laws and regulations at home and abroad, professional teaching ability, and Business English two-way teaching ability. Some scholars also put forward opinions on the capabilities and qualities of Business English teachers in China based on empirical research results. For example, Guo and Li (2015), based on the theory of ESP Needs Analysis, according to the employment survey report of the University of Mickey Data Co., Ltd., combining with the professional quality structure design questionnaire for Business English teachers, investigated the professional quality of Business English teachers in China. On the basis of the results of the questionnaire survey, the existing problems of Business English teachers are discussed, and suggestions for improvement are provided on the professional qualities and development of Business English teachers. Wang and Zhang (2011) conducted questionnaire surveys and quantitative research on Business English students and teachers at 13 representative universities in China as well as company employees engaged in business English related work. The study finds that Business English teachers have their own unique competence characteristics. In addition to the need to improve the individual professional qualities of Business English teachers, it is necessary to strengthen the complex construction of the Business English as a whole. Generally speaking, domestic scholars have made remarkable achievements in this research field, with both theoretical research and empirical research. However, the number of empirical studies is relatively small, and most of the empirical studies used questionnaire as the research means, so the form of research is relatively simple. In the future research, we hope to have more empirical research, which will take different research means, such as classroom observation, personal visit and so on, or using a combination of various research means.

\section{Theoretical Framework}

Domestic and foreign scholars' research on ESP involves many fields, including the definition and classification, Needs Analysis, pedagogy research, and curriculum design. The theoretical framework of this paper mainly involves two aspects, namely Needs Analysis and Learning-centred approach of ESP theory. Needs Analysis and Learning-centred approach can be organically integrated with the development of Business English teachers, providing them with inspiration to construct multiple teacher identity.

\subsection{Needs Analysis}

Hutchinson and Waters (2002) believe what distinguishes ESP from General English is not the existence of a need as such but rather an awareness of the need. If learners, sponsors and teachers know why learners need English, this awareness of needs will affect the acceptability and rationality of language course design. Any course should be based on the needs of learners. Many linguistic experts have defined Needs Analysis, such as Munby (1978), Richteric and Chancere (1978) and Dudley-Evans and St. John (1998). This article mainly uses the definition given by Hutchinson and Waters (2002), that is, Needs Analysis is a complex process. It does not only design what the learner wants to do in the target context. More importantly, it must consider both the needs 
of context and the learning requirements. Huang (2007) believes that Needs Analysis is a unique and necessary condition for professional English or English for Specific Purposes. Only by fully understanding the needs of the learners can a better course design be made after a detailed analysis. The Needs Analysis of ESP enlightens us that Business English teachers can better design Business English courses and better achieve teaching goals only if they fully know and analyze the needs of Business English learners.

\subsection{Learning-centred Approach}

Hutchinson and Waters (2002) put the emphasis of teaching ESP on the learning process in their book "English for Specific Purposes" in 1987, and proposed Learning-centred approach. They believe that a truly effective approach to learning ESP must be based on an understanding of the language learning process. They also discussed the role of ESP teachers in ESP teaching activities and the difference between teachers engaged in ESP teaching and teachers engaged in EGP teaching. They believe that ESP teachers do not need to learn specialist subject knowledge. They require three things only:1) a positive attitude towards the ESP content. 2) a knowledge of the fundamental principles of the subject area; 3 ) an awareness of how much they probably already know. The ideas on teachers' roles under Learning-centred approach can also provide guidance for the identity construction of Business English teacher to help them build their professional identities scientifically which will be discussed in more detail in the following part.

\section{Research Questions and Method}

\subsection{Research Questions}

This paper, from the perspective of ESP theory, combining previous viewpoints and the findings of actual Business English teaching class, aims to answer the following two research questions: 1) What teacher identities should Chinese Business English teachers construct? 2) How to achieve the construction of these identities?

\subsection{Research Method}

This paper adopts a combined research method of literature analysis to carry out qualitative analysis. We observed the teaching activities in four 4 courses offered by Guangdong University of Foreign Studies for their first-year postgraduate students of Business English major, namely, "Theoretical Research on Business English" "Research on International Business", "Marketing" and "Accounting". Guangdong University of Foreign Studies is one of the first schools which offered Business English as an undergraduate and postgraduate program, so it is representative in the field of Business English teaching. The study conducted a one-month classroom observation. The main search means is to attend lectures or listen to class recordings, collect details in class and to make simple written records according to general observation outline. Then, it collects the results of the classroom observation, and makes a qualitative analysis on the construction of teacher identity based on the results and some basic information about the professional identity of the teachers collected from the official website of the university. Since there is quite limited number of observation subjects in this study and the results are not data-supported, it is only for references and the main discussion and analysis is from the qualitative analysis of previous studies.

\section{Identity Construction of Business English Teachers}

Based on the previous studies and the practical class observation, we found that different from General English teachers, there are a lot of specialized abilities and competence required of qualified Business English teachers. Therefore, we need to find an identity orientation for Business English teachers which are different from General English teachers, so as to build a more comprehensive, more general and appropriate BE teacher identity. It is concluded that the business English teachers should construct the following three teacher identities: teaching practitioner and researcher, learner and businesspeople. The following is a detailed discussion of these three kinds of teacher identity.

\subsection{Teaching Practitioners and Researchers}

We believe that Business English teachers must first be teachers who impart knowledge and solve doubts of the students, and the main function of teachers is the practitioner of teaching. But because Business English program cultivates interdisciplinary talents, so the teachers who are engaged in the professional teaching must also be high-quality talents with both English knowledge and business knowledge as well as rich business practical experience. Only those Business English teachers who have strong professional knowledge reserves and rich experience in business practice can help solve doubts of students and provide them more practical guidance to satisfy their needs so as to cultivate professional talents to meet the needs of society and countries. In addition, since Business English is a new discipline, its professional development and construction are still in a relatively immature stage, so more scholars need to contribute themselves to the disciplinary development. This requires 
Business English teachers besides working hard in the front line of teaching practice, and more importantly, they are to be a conscientious teaching researcher on the preparation of Business English textbooks, curriculum design, professional testing, disciplinary construction and other aspects. Moreover, due to the particularity of Business English, the teachers are encouraged to participate in all the aspects of the whole teaching process so as to fully consider and satisfy the needs of the learners and society. Through this process, the teachers can be more familiar with their teaching processes, which is helpful for them to produce new ideas and concepts in Business English learning and teaching promoting Business English disciplinary development. Business English teachers can also combine their experience of individual teaching practice to explore the characteristics of Business English and effective teaching modes, and through continuous reflection, to form a set of teaching concepts and theories from practice, and eventually become introspective teaching practitioners. Some of the Business English teachers surveyed this time showed this identity characteristic. They not only deliver courses to students in the classroom, but also doing a lot of research in this area. For example, Professor Guo $(2018,2015)$ has made great contributions in the research on the development of Business English teachers. Professor Zhang (2014) has contributed a great deal to the compilation of Business English teaching materials.

\subsection{Learner}

As mentioned above, due to the special characteristic of Business English, teachers engaged in Business English teaching must also have an interdisciplinary knowledge and skills of English and business. Does this mean that Business English teachers must be experts in both fields? Hutchinson and Waters (2002, p. 53) pointed out that ESP teachers do not need to learn specialist subject knowledge. They require three things only: 1) a positive attitude towards the ESP content. 2) a knowledge of the fundamental principles of the subject area; 3) an awareness of how much they probably already know. Similarly, we believe that Business English teachers do not necessarily have to be experts in both English language and business. Rather they need to be aware of their multiple teacher identity, fully comprehend their own teaching curriculum, and maintain a positive and active attitude toward their teaching and keep learning in practice which can make them a qualified Business English teacher. Although based on the views of Hutchinson \& Waters, we can deduce that English teacher do not need to become an expert in both general English language and general business, we believe they still have to make great efforts to become an export in the their specific teaching field like for a teacher teaching "Accounting" for Business English students, if he has comprehensive knowledge about both Accounting and English language, the students will have much to learn and can better serve the demanding requirements caused by the fast development of the society. Moreover, in their theory of learning-centred approach, Hutchinson \& Waters put emphasis on the learning process. They believe that ESP teachers do not need to become teachers in a certain field but become students interested in this field. Similarly, Business English teacher is also a learner. Considering Business English Program and its discipline development in China is still in an immature stage, there will be possibly more and more brand-new ideas and concepts to be proposed in the near future, which needs Business English teachers to keep learning and update their teaching methods accordingly. The rapid development of the society also requires the teachers to have a lifelong learning spirit so as to keep up with the time and to cultivate talents satisfying the changing social needs. In practical teaching activities, teachers can constantly find their own deficiencies and learn new knowledge from the practice and even from their students. This point can also be explained by the opinions of external factors influencing the construction of teacher identity in teacher identity research.

\subsection{Business People}

The Needs Analysis theory of ESP suggests that the biggest difference between Business English and General English should lie in the awareness of learners' needs. According to the National Criterion, the Business English program aims to cultivate interdisciplinary and applied talents who have solid foundation in English ,with an international perspective and humanistic qualities, mastering basic theories and knowledge such as linguistics, economics, management, and law (International Commercial Law), familiar with the rules and practices of international business and who are equipped with practical ability to apply English skills, business practice skills, cross-cultural communication skills, critical and creative capabilities, and independent learning abilities to engage in international business workplace. The end result lies in "applied talents," which shows the importance of practical ability for Business English. Therefore, teachers engaged in Business English teaching must pay much attention to develop students' competence of application and practice, which means they should have the awareness and ability to consider and analyze the practical needs of learners first and then to develop students' practical and professional abilities in a proper way. Creating a simulated business teaching environment is of great significance developing students' practical business abilities, which requires the Business English teachers and the students to act as a "business people" in simulated business contexts. The "business people" here does 
not mean that Business English teacher must be both a teacher at school and an employee at a company at the same time, but that Business English teacher needs business experience in real-world and has the ability to provide students with simulated real business contexts in class and give them guidance in doing the simulated business tasks. For example, in a class of "Marketing" course in this observation, its teachers acted as a business people and set problems for students in actual business activities. For example, one task at a time was to allow students to act different business roles to conduct a feasibility analysis for a training institution in Guangzhou who would rent a store in a newly opened shopping mall in Guangzhou, and then they were to act as a stakeholder to report the survey they have done. In this process, the teacher not only acts as organizers and coordinators, but also plays the role of business people because the teacher as an initiator and supervisor of the entire task needs to design business issues, simulate business contexts, and to provide business guidance for the student.

However, in the future, the identity of BE teachers is not limited to this, and it may be expanded. At present, there is no common consensus on the BE teachers' identity, but only after fully understanding the particularity of BE teachers' identity, we can construct a BE teacher identity construction model. No matter how many dimensions of identity there are for a Business English teacher, the purpose of exploring it is to promote the identity construction of BE teachers and the development of BE education.

\section{Practical Approaches to Identity Construction of Business English Teachers}

Based on the previous researches on teacher identity, we know that the construction of teacher identity can be influenced by both internal personal and external contextual factors, therefore, this article presents the following views on the successful construction of the multiple teacher identity of Business English teachers from two perspectives, the personal side-the teachers themselves and the contextual perspective-the universities and colleges. First of all, Business English teacher themselves must be aware of their multiple identities as a Business English teacher, and they should actively make efforts in teaching practice to make up for their own shortcomings and strive to be equipped with the multidimensional abilities required of Business English teachers. For example, teachers with only English language professional background can go for further study in business, and the teachers with only business background actively learn more English language knowledge to improve their English level. In this classroom observation, some Business English teachers who teach business classes do not have the educational background of English language and literature, showing problems in expressing themselves clearly in English. Therefore, this part of teachers needs to realize their shortcomings and take the initiative to enhance their English expression ability in different ways. Second, the interaction between teachers is also very helpful. More academic exchanges should be held where teachers can share their individual teaching experiences and conduct self-reflection on their teaching methods which can help the teachers remove frustration and make progress in their professional development. For the universities and colleges, there are a lot they can do to support Business English teachers construct multidimensional identity. First, more opportunities should be provided for Business English teachers to enhance their interdisciplinary professional abilities. For example, some on-the-job training can be held on a regular basis to help the teachers fill the gaps and update their knowledge. Teachers can also be organized to visit and conduct academic tours at universities at home and abroad which have a good reputation for Business English program to know the latest development in this field. External experts in the field can also be invited to the campus to bring teachers the latest information and give some professional training. Teachers who lack practical experience can be encouraged and supported to visit companies regularly to learn more about the practical operation of business. Besides, establishing free and open $\mathrm{BE}$ teacher exchange platforms can be an effective way to help the majority of BE teachers to exchange teaching experience. Experienced teachers can answer questions for new teachers, and new teachers may bring new teaching ideas and concepts to their predecessors.

\section{Conclusion}

Business English is a branch under English for Specific Purposes. It is closely related to ESP and has a great difference from General English in terms of teaching mode, teaching theory, and personnel training and so on. In the face of the uniqueness of Business English, Business English teachers in China must pay attention to the uniqueness of their professional identity and actively construct multidimensional teacher identities to meet the requirements of new environment and to achieve self-professional development. This paper discusses the identity construction of Business English teacher from the perspective of ESP, which is of great significance to help Chinese Business English teachers succeed in constructing multiple teacher identities, realizing professional development, and promoting the development of Business English program and discipline in China. It is suggested in the paper besides BE teachers' personal efforts to build self-consciousness of multidimensional identity and take actions to enhance their personal interdisciplinary competence, the universities and colleges 
should also create a favorable environment for the teachers to achieve their construction of identities by means of providing them with various opportunities to fill the gap and get professional improvement. There are still many deficiencies in this study. First, the research method is qualitative analysis, lacking empirical research with data support. Second, the observation in this study only covers teaching activities in four classrooms at one university, which lacks universality. Finally, considering teacher identity is not fixed, and it will continue to change under the influence of various factors, the three kinds of identities of Business English teacher proposed in this paper are still far from enough, which need to be constantly updated in the subsequent studies. In short, though with much room for improvement, this paper aims to provide a new perspective for research on the professional development of Business English teachers, and hopes to provide some reference for the future research in this area.

\section{Acknowledgements}

This research was supported with funds from Guangdong University of Foreign Studies under the provincial research project of the Career Development Strategies and Practices for Business English Teachers under the Guide of National Criteria for Teaching Quality of Undergraduate Programs. The support is gratefully acknowledged.

\section{References}

Arvaja, M. (2016). Building teacher identity through the process of positioning. Teaching and Teacher Education, 59, 392-402. https://doi.org/10.1016/j.tate.2016.07.024

Beauchamp, C., \& Thomas, L. (2009). Understanding teacher identity: an overview of issues in the literature and implications for teacher education. Cambridge Journal of Education, 39(2), 175-189. https://doi.org/10.1080/03057640902902252

Beijaard, D., Meijer, P. C., Verloop, N. (2004). Reconsidering research on teachers' professional identity. Teaching and Teacher Education, 20(2), 107-128. https://doi.org/10.1016/j.tate.2003.07.001

Goodson, I. F., \& Cole, A. L. (1994). Exploring the teacher's professional knowledge: Constructing identity and community. Teacher Education Quarterly, 21(1), 85-105.

Guo, G., \& Li, D. (2015). Professional quality and development of Business English teacher-based on ESP Needs Analysis. Journal of PLA Foreign Languages, 38(5), 26-32.

Guo, G., \& Li, D. (2018). Identity Transition and Career Development of Chinese BE Teachers under the Context of BELF, Higher Education Studies, 8(2), 1-8. https://doi.org/10.5539/hes.v8n2p1

Huang, P. (2007). The theory and application of ESP. Chongqing: Chongqing University Press.

Hutchinson, T., \& Waters, A. (2002). English for Specific Purposes-A learning-centered approach. Shanghai: Shanghai Foreign Language Education Press.

Li, X. (2018). Research on the Professional Development Needs of Business English Teacher in Colleges and Universities. Journal of Hubei Open Vocational College, 31(22), 152-153.

Li, Z., Liu, Y., \& Wei, M. (2017). The construction of teachers' Multi-dimensional identity under the flipped classroom mode-Taking English writing course as an example. Journal of the Northwest Adult Education Institute, 4, 54-60.

Lu, M. (2017). Identity construction and construction of teaching staff of ESP teachers. Journal of Qiqihar Teachers College, 1, 137-139.

Mo, L. (2008). The teaching and research of ESP. Hangzhou: Zhejiang University Press.

Ren, R. (2013). ESP teachers' standards, team building and professional training. Teacher Education Research, 25(5), 76-80.

Volkmann, M. J., \& Anderson, M. A. (1998). Creating professional identity: Dilemmas and metaphors of a $\begin{array}{llll}\text { first-year chemistry teacher. Science } & \text { Education, } & \text { 82(3), }\end{array}$ https://doi.org/10.1002/(sici)1098-237x(199806)82:3<293::aid-sce1>3.0.co;2-7

Wang, G., \& Zhang, H. (2011). A study on the elements of Teacher competence in the development of Business English discipline. Foreign Language World, 6, 15-21.

Wang, L. (2015). Interpretation of national standards for teaching quality of Business English Program. Foreign Language Teaching and Research, 47(2), 297-302.

Wang, L., \& Ge, H. (2016). On the development of professional competence of Business English teachers under 
the guidance of "national standards". Foreign Language World, 6, 16-22.

Wang, Y., Wang, G., \& Zheng, L. (2014). Investigation and Enlightenment on the demand and training mode of Business English talents. Foreign Language World, 2, 34-41.

Wang, Z., \& Bai, X. (2015). Identity construction and professional development of Business English teacher. Journal of Jixi University, 15(5), 15-17.

Weng, F. (2015). Research on Business English: Microcosmic and macroscopic. Foreign Language Teaching in Shandong, 36(6), 28-35.

Xiang, Y. (2009). A review of the research on identity construction. Social Science Research, 5, 188-192.

Xu, J., Qin, L., \& Yang, W. (2017). Identity in the Development of Foreign Language Teachers' Professional Development-A Case Study of a High School Novice English Teacher. English Teachers, 17(20), 149-153

Yue, T. (2016). A review of the research on the identity construction of English teachers in China. English Teachers, 9, 67-69.

Zhang, Q. (2011). Case study on identity construction of online English teachers. Journal of Guangxi Vocational and Technical College, 4(6), 41-44.

Zhang, W. (2014). Research on Business English Program and Discipline. Beijing: Foreign Language Teaching and Research Press.

Zhang, Y., \& Tang, Y. (2012). Research on the construction of teachers' ability elements in Business English. The Science Education Article Collects, 11, 106-107.

Zhu, M. (2019). Discussion on Teacher Identity Construction Based on Three Learning Theories. Teacher Education Research, 31(1), 12-23.

\section{Copyrights}

Copyright for this article is retained by the author(s), with first publication rights granted to the journal.

This is an open-access article distributed under the terms and conditions of the Creative Commons Attribution license (http://creativecommons.org/licenses/by/4.0/). 